Finanse, Rynki Finansowe, Ubezpieczenia nr 4/2018 (94), cz. 1

DOI: $10.18276 /$ frfu.2018.94/1-08

s. $91-98$

\title{
Integrated reporting - changes in company reporting
}

\author{
Joanna Błażyńska*
}

\begin{abstract}
Purpose - This article traces the changes in company reporting resulting in preparing an integrated report.

Design/methodology/approach - Analysis of reference works, case study, deduction method and conclusion synthesis.

Findings - The analysis results for annual company reports over several years were presented, from the inclusion of the first information on the social responsibility to the preparation of an integrated report.

Originality/value - Evolutionary approach to financial reporting, including the influence of non-financial company activity aspects on its value creation, is presented.
\end{abstract}

Keywords: integrated reporting, annual reports, company market value, social responsibility

\section{Introduction}

Companies strive to adopt practical solutions in their operations which result in maximizing company value in a short- and long-term perspective. Maintaining proper relationships with broadly-taken stakeholders is of key importance for the value creation. This does not refer solely to capital providers but also to the company perception by all market participants. Socially and environmentally benevolent behaviours are standard today (analysis by TNS Polska, 2015). The stakeholders are interested not only in the results achieved, but also in the social responsibility within the sustainable development concept. In the decision-making processes, the strategy adopted and company activity perspectives are often more important than the profit. The company response to the above postulates is integrated reporting, comprising both financial and non-financial information. Integrated reporting is a relatively new reporting concept which seems to be rooted permanently in the annual company reports. The absence of a uniform standard of the integrated report preparation and presentation causes many problems to companies. This is one of the major factors delaying introduction of the said report in practice, although it is stressed that the integrated reporting improves the usability of the information presented and exerts a favourable influence on the decisionmaking processes of stakeholders. The regulations resulting from implemented provisions of Directive as regards disclosure of non-financial and diversity information by certain large

* dr hab. Joanna Błażyńska prof. UEP, Poznań University of Economics and Business, e-mail: joanna. blazynska@ue.poznan.pl 
undertakings and groups (Directive 2014/95/EU), in force since 1 January 2017, are bound to contribute to the growing popularity of presenting non-financial information. Companies not covered by the directive will probably do it at their own discretion, in line with voluntary disclosure theory (Bayer, Cohen, Lys, Walther, 2010) to improve communication with stakeholders and increase usability of the presented reports.

This article is aimed at studying changes in company reporting and company strive to ensure integrated reporting. The study is devoted to annual reports and the study subject is a company which has prepared its first integrated report. The purpose of the article is to trace changes in company reporting which, as a result, led to the integrated report preparation. To achieve the article purpose, adequate study methods had to be employed. Analysis of reference works, case study, deduction method and conclusion synthesis were used.

\section{Literature review}

The grounds for company reporting are the need to provide useful information to stakeholders, i.e. information having specific quality features, required in a given situation for a specific purpose (Błażyńska, 2015, p. 45).

The company objectives evolve in time, but they are usually related to their increased market value. If the company adopts solely financial aspects as its objectives, it pursues the owners' goals without considering expectations of other stakeholders' groups. Exorbitant profit requirements are only rarely accompanied by ethical approach which may be perceived as one of causes of the recent global financial crisis (Marcinkowska, 2011, p. 855). Focusing on recipients and their expectations concerning company reporting, it is necessary to differentiate between two approaches in the relationship between the company and its stakeholders, namely the authority dependence and legitimization approach (Chen, Jermias, Nazari, 2016). The first of them refers to indicating groups having relationships with the company because of a specific "interest". In the second approach, compliance with the law, rules and regulations in force in a given community is what counts most, i.e. the ethical approach. This approach is based on the assumption that the company operations are compliant with the system of social standards and values.

In recent years, the company market value has been based, to a growing degree, on nonmaterial resources, e.g. intellectual, social, human capital, research, development and innovation (Integrated Reporting..., 2014). To create value in time, companies must manage a wide range of resources proactively, as the notion of the value changes in line with the global economy dynamics. This means they create value not only for the owners, but also for the society within the sustainable development concept.

Capital markets, both global and local ones, largely depend on information provided by companies. Useful information is grounds for effective capital allocation and ensuring appropriate investment climate. This requires a structured presentation of financial and non-financial information. 
Integrated reporting combines traditional financial accounting with sustainable development and corporate governance to improve information usefulness in a decision-making process in the field of cutting-edge company reporting (Velte, Stawinoga, 2017). The report is to show how the nonfinancial activity aspects influence the company ability to generate value in the short-, medium- and long-term perspective. This is why it refers to strategies, management, results and perspectives of the company.

Integrated reporting is an international initiative concerning corporate reporting which is to limit employment of various reporting strategies causing informational chaos (Zhou, Simnett, Green, 2017). Even though the integrated reporting concept popularity has been growing, the evidence of its application benefits has still been looked for.

There have been studies of changes in company reporting as a result of implementing GRI guidelines and the impact of the presented integrated reports on the company market value (Beck, Dumay, Frost, 2017; Velte, Stawinoga, 2017). The reference works clearly display the study trend related to the position of the International Integrated Reporting Council, namely that the integrated reporting improves report usefulness for investors. It was proved that the advantages of integrated reporting may exceed the costs of the report implementation in companies with complex operating and informational environment, resulting in reduced information processing costs. A positive relationship between the integrated reporting and the company valuation refers primarily to large companies with many business segments (Lee, Yeo, 2016; Zhou, Simnett, Green, 2017). Other studies observed reduced net value of assets which was ascribed to disclosures related to risk and unsecured liabilities (Diogenis, Gunnar, 2016). According to other studies, the ability to disclose CSR activities in reports provides an incentive for managers to invest in CSR (Chen, Jermias, Nazari, 2016).

However, it should be emphasized that despite the integrated reporting advantages proven by the studies, such as future orientation, improved information quality in an annual report, ensuring improved understanding of results affecting company value generation in time or effect on improved performance of the company as a whole (Integrated Reporting, 2017), the problem has been the absence of their integrity and reliability (Diouf, Boiral, 2017). Besides the report form recommended by IIRC, also the G4 GRI guidelines may be useful (GRI, 2016). According to KPMG (2013), 93\% of 250 largest companies worldwide have already published their reports based on GRI.

\section{Data and methodology}

Since 2009, the Respect Index has been the index of responsible companies, comprising Polish and foreign companies on the Main Securities Market of the Stock Exchange. The index consists of companies which pass a three-tier verification carried out by the Stock Exchange and the Polish Association of Listed Companies, communicate with the market by means of current and periodic reports, as well as websites, and behave in a socially responsible way towards the environment, community and employees. The $9^{\text {th }}$ edition of the 
Respect Index comprised 28 companies (since 18 December 2017). The financial sector is a strong group with 9 companies, including 7 banks.

The study employed a teleological method. The study subject is ING Bank Śląski (ING) which has been included in the Respect Index constantly since the very first listing. ING started to report its social responsibility in 2009 and prepared the first integrated report for 2009. This is why the first study period covers years 2009-2016 and the study subject is annual ING reports.

The analysis focused on changes in the information presented in the annual reports, with particular attention devoted to the disclosure and presentation of non-financial information.

\section{Analysis and Findings}

The annual reports of ING comprised:

- an opinion of an independent expert auditor, confirming ING presents all information indispensable to evaluate the business activity result for a given period in a reliable and clear way, in compliance with IFRS and legal regulations on financial statement preparation, affecting their form and contents (opinions with no reservations),

- a report complementing the opinion of the independent expert auditor on the audit of the consolidated financial statement for a given year,

- an annual consolidated financial statements of the Group: consolidated profit and loss account, statement of comprehensive income, statement of financial position, statement of changes in equity and cash flow statement (187 pages in 2009, 198 pages in 2016),

- Management Board report on the Group operations (79 pages in 2009, 116 pages in 2016).

Throughout the whole period the report structure was consistent which exerts a favourable influence on the information comparability.

In the Management Board report of 2009, the description of ING as a socially responsible financial institution is a one-page description of operations in four areas, namely Business/ Customer relationships, in the workplace/towards employees, in the environment and in community relations (volunteering, ING for Children Foundation, ING Polish Art Foundation).

In the subsequent year, the description of areas where CSR strategy was implemented did not change much, but more attention was devoted to forms of communicating with customers (forum, Skype, Facebook, blip.pl accounts, YouTube video channel) and the implementation of ISO 14001 (Environmental Management System).

In 2011, the annual report was made available online for the first time, on a user-friendly website (operations, bank authorities, reports, information for investors, risk management). The information on the social responsibility ensured by ING was published in a separate tab. Broadcasts of the Ordinary and Extraordinary Shareholders' Assembly were introduced. ING took the first place in the ranking of Socially Responsible Companies in the Banking and Finance category. 
In 2012, ING received a leader position in the ranking of Socially Responsible Companies. The vision and development plans of ING were included in the "Corporate Social Responsibility Strategy ING Bank Śląski SA 2011-2012” (58 pages). The report was based on GRI 3.1 guidelines, level B. It emphasized the key role of activities related to the corporate social responsibility for achievement of ING business objectives.

In 2013, the report called "ING Art of Responsibility" [ING Sztuka Odpowiedzialności], compliant with GRI, was published, summarizing the most important socially responsible activities undertaken by ING in 2011-2012 (assumption of performance progress, business and social activity statistics, key stakeholders).

In the following year, preparing the Social Responsibility Report for 2013-2014, in compliance with GRI G4 guidelines, a significance study was carried out to find the most important aspects of ING activity (using the Account Ability Stakeholder Engagement Standard, AA 1000SES). ING took the first place in the responsible companies' ranking. In the same year, the Regulation of the European Commission (EU) no. 604/2014 with respect to qualitative and appropriate quantitative criteria to identify categories of staff whose professional activities have a material impact on an institution's risk profile was implemented into the internal regulations of ING.

In 2015, ING published the report as "Responsibility in Closeup" (Odpowiedzialność w obiektywie). It included a significance matrix in combination with 10 key activity reporting aspects proposed by stakeholders, including innovative initiatives and openness to dialogue.

ING prepared the first integrated report for 2016 based on GRI G4 guidelines, with the basic option, and in accordance with IIRC integrated reporting guidelines. The report preparation was preceded by surveys among analysts, investors and employees. The most important proposals of respondents are included in Table 1.

\section{Table 1}

The most important areas according to the respondents

\begin{tabular}{ll}
\hline $\begin{array}{l}\text { Group of } \\
\text { respondents }\end{array}$ & Area \\
\hline 1 & 2 \\
\hline Analysts & - strategy and its performance \\
and investors & - dividend policy priorities \\
& - market context, development opportunities and plans \\
& - diversity and equal opportunities among employees \\
& - key stakeholders and relations with them \\
& - improved management efficiency \\
& - company against its competitors in Poland \\
& - environmental effect of the financed investments \\
& - human capital quality \\
\hline
\end{tabular}




\begin{tabular}{ll}
\hline 1 & 2 \\
\hline Employees & - corporate culture \\
& - relationships and dialogue with employees \\
& - knowledge management \\
& - training and ways to ensure employee development \\
& - company against its competitors in Poland \\
& - awareness building among employees and advisers (socially and environmentally \\
& benevolent campaigns) \\
& - information on the social involvement activities of the bank and their outcomes \\
& - employee volunteering \\
\hline
\end{tabular}

Source: own compilation based on ING (2017).

The report was structured based on the following priorities:

a) key significance: innovations for customers, products and company development, customer safety, ethical information on products and services, customer relation management, dialogue with customers, openness to their opinions and needs, customer education, employee training and development, service quality, economic results, financing environmentally-friendly investors and investments, compliance (and regulation development), versatility, non-discrimination, equal opportunities, table IT systems and platforms, responsible award of loans and preventing debts, product and service valuation, risk management, no bribery, employee remuneration;

b) medium significance: dialogue with stakeholders, ING against competitors in Poland, strategy disclosure and performance, ING priorities related to dividend policy, market context, development opportunities and plans, improved management efficiency.

The most important but also the most difficult integrated report component was to develop a value generation model providing answers to the following questions: what value does ING generate for stakeholders and community? how does ING measure and maximize value?

The analysis of ING potential, costs and outcomes was carried out. The benefits were analysed based on the improved human capital quality, increased organization intellectual capital, production capital in the form of offered products and services, with their provision quality, financial capital, social and relational capital.

\section{Conclusions}

The study proves how challenging the integrated report preparation is for a company. Since 2009, every Management Board report on ING operations included a chapter devoted to social responsibility, but only in 2012 the first report devoted solely to the corporate social responsibility was prepared. The integrated ING report for 2016 provides an outline of its financial and non-financial activity. It is a continuation of the annual reports published previously, containing social responsibility data, but the integrated report is not focused on adding other non-financial aspects but on presenting the impact of internal and external conditions on generating company value in a short-, medium- and long-term perspective. Such aspects 
as the social responsibility strategy or business model are not permanent. This is why it is worth having a closer look at the evolution of the integrated ING report in subsequent periods.

\section{References}

Analiza TNS Polska dla Ministerstwa Środowiska (2015). Raport z analizy badań świadomości postaw i zachowań ekologicznych Polaków przeprowadzonych w Polsce w latach 2009-2015. TNS.

Beyer, A., Cohen, D., Lys, T., Walther, B. (2010). The Financial Reporting Environment: Review of the Recent Literature. Journal of Accounting and Economics, 2-3 (50), 296-343.

Beck, C., Dumay, J., Frost, G. (2017). In Pursuit of a "Single Source of Truth": from Threatened Legitimacy to Integrated Reporting. Journal of Business Ethics, 1 (141), 191-205.

Błażyńska, J. (2015). Użyteczność informacji finansowych sprawozdań finansowych. Poznań: Wydawnictwo Uniwersytetu Ekonomicznego.

Chen, Y., Jermias, J., Nazari, J. (2016). The Effects of CSR Reporting Frameworks and Financial Conditions on Managers' Willingness to Invest in CSR. Retrieved from: http://dx.doi.org/10.2139/ssrn.2711053.

Diogenis, B., Gunnar, R. (2016). Value Relevance of Accounting Information under an Integrated Reporting Approach: A Research Note. Journal of Accounting and Public Policy, 4 (35), 437-452.

Diouf, D., Boiral, O. (2017). The Quality of Sustainability Reports and Impression Management: A Stakeholder Perspective. Accounting, Auditing \& Accountability Journal, 3 (30), 643-667.

Directive of the European Parliament and of the Council no. 2014/95/UE of 22 October 2014 Amending the Directive 2013/34/UE as Regards Disclosure of Non-Financial and Diversity Information by Certain Large Undertakings and Groups. Official Journal UE L 330/1.

GRI (2016). Wytyczne dotyczące raportowania G4. Zasady raportowania i wskaźniki. Retrieved from: www. globaltrporting.org.

ING (2017). Jak powstawat raport zintegrowany. Retrieved from: https://www.raportroczny.ingbank.pl/pl/jakpowstawal-raport-zintegrowany.html.

Integrated Reporting. Elevating Value (2014). EYG No. AU2354.

Integrated Reporting (2017). Retrieved from: https://integratedreporting.org.

KPMG (2013). International Survey of Corporate Responsibility Reporting 2013. Amsterdam. Retrieved from: www.kpmg.com/Global/en/IssuesAndInsights/ArticlesPublications/corporateresponsibility/Documents/ corporate-responsibility-reporting-survey-2013.pdf.

Lee, K., Yeo, G. (2016). The Association Between Integrated Reporting and Firm Valuation. Review of Quantitative Finance and Accounting, 4 (47), 1221-1250.

Marcinkowska, M. (2011). Tworzenie wartości przedsiębiorstwa dla interesariuszy. Zeszyty Naukowe Uniwersytetu Szczecińskiego, 639. Finanse, Rynki Finansowe, Ubezpieczenia, 37, 855-870.

Velte, P., Stawinoga, M. (2017). Integrated Reporting: The Current State of Empirical Research, Limitations and Future Research Implications. Journal of Management Control, 3 (28), 75-320.

Zhou, S., Simnett, R., Green, W. (2017). Does Integrated Reporting Matter to the Capital Market? ABACUS. A Journal of Accounting Finance and Business Studies, 1 (53), 94-132. 


\section{RAPORTOWANIE ZINTEGROWANE - CZAS ZMIAN W SPRAWOZDAWCZOŚCI JEDNOSTEK}

Streszczenie: $\mathrm{Cel}$ - Celem artykułu jest prześledzenie zmian w sprawozdawczości, prowadzących do sporządzenia raportu zintegrowanego.

Metodologia badania - Analiza literatury, analiza przypadku, metoda dedukcyjna i synteza wniosków.

Wynik - Przedstawiono wyniki analizy raportów rocznych jednostki na przestrzeni kilku lat, tj. od ujęcia pierwszych informacji o społecznej odpowiedzialności do przygotowania zintegrowanego raportu.

Orginalność/wartość - Zaprezentowano ewolucyjne podejście do sprawozdawczości finansowej, w której raportuje się, jak pozafinansowe aspekty działalności jednostki wpływają na tworzenie jej wartości.

Słowa kluczowe: raportowanie zintegrowane, raporty roczne, wartość rynkowa jednostek, społeczna odpowiedzialność

\section{Citation}

Błażyńska, J. (2018). Integrated Reporting - Changes in Company Reporting. Finanse, Rynki Finansowe, Ubezpieczenia, 4 (94/1), 91-98. DOI: 10.18276/frfu.2018.94/1-08. 